\title{
Variables Impacting Poultry Meat Quality from Production to Pre-Slaughter: A Review
}

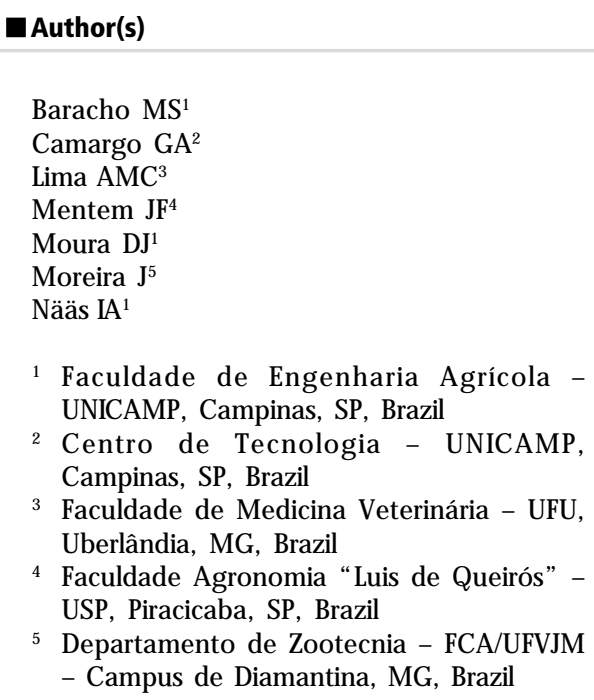

Mail Address

MS Baracho

Faculdade de Engenharia Agrícola - UNICAMP CXP. 6011

13.083-970. Campinas, SP, Brazil

\section{Keywords}

Meat hygiene, meat quality, pre-processing, production chain.

\section{ABSTRACT}

Poultry meat quality has been widely studied, and has become a growing demand of the international market. Parameters that affect meat quality are complex, and occur throughout the production chain. The constant concern with meat quality by the exporting sectors is a response to consumers' demands, and is achieved by increasing efficiency, and investments in personnel training on quality. Understanding where critical points are in the poultry meat production chain, and investing in solving critical problems may lead to better control and management, and consequent reduction of losses. Production and management practices, from farm to processing plant, play an important role in meat quality, and the use of technologies to reduce risk factors throughout the production chain will allow the production of better quality poultry meat not only for exports, but also for the domestic market. This review describes the main factors that influence poultry meat quality in the production chain.

\section{INTRODUCTION}

Brazil is the world's largest beef and poultry exporter, and fourth largest pork exporter, with total meat sales generating over USD 8 billion in 2005. Brazil achieved this position over the past decade, as Brazilian agriculture benefited from macroeconomic stability, high international commodity prices, currency devaluations, technological advancements, expansion in arable land area, and large capital inflows from domestic and direct foreign investment. Domestic policies (credit and tax-exemption programs) also spurred production and processors' incentives. Brazil's poultry meat exports account for $41 \%$ of global trade (UBA, 2005; Valdes, 2006).

Even though the United States is the largest poultry meat producer, Brazil is the second, and this position occasionally alternates. When adding to this figures other Latin American producing countries, such as M exico, Colombia, and Argentina, the continent concentrates nearly $50 \%$ of the world's poultry meat production.

Broiler production in Brazil has become a very competitive activity during the last few years. Constant innovation lead to higher productivity while maintaining the same production cost, which is a desirable situation. One recent trend in Brazilian broiler production is to increase bird density, which requires the environmental control of poultry houses through the use of fan and fogging systems in order to achieve better live performance. Modern poultry production techniques, associated to better breeding management and health control, led to higher feed conversion ratio and improved production efficiency. Available literature (Xin et al., 1994; Tinôco, 2001; Aradas et al., 2005) indicates that improved environmental control of the broiler houses has played an 
Baracho MS, Camargo GA, Lima AMC, Mentem JF, Moura DJ, Moreira J, Nääs IA

Variables Impacting Poultry Meat Quality from Production to Pre-Slaughter: A Review important role in the increase in the productivity of the poultry industry, particularly in tropical areas, or those experiencing hot summer conditions.

According to Lima (2005), success in broiler production is directly associated to economical feasibility, qualified labor, intensive use of good practices, and a close link with the consumer market. Each of these items bears specific importance; however, they have to be considered in a multidisciplinary way, as these factors are overlapping. Average-size and small broiler production have met increasing difficulties to remain economically feasible in the present model of vertical structured production due to the necessary initial investment in housing, environmental control, etc.

Heier et al. (2002) recorded high mortality rates and other economical losses during the first w eeks of broiler rearing, emphasizing that incorrect management and environmental control routines at this stage may cause significant losses.

Due to the market demand for quality, Brazilian processing plants are constantly implementing quality programs, as well as standards to obtain ISO 9000 certification. In addition, there is trend to produce broiler free from chemical, biological, and physical contaminants due to food safety concerns. This results in health and management constraints, as well as in limitations in the control of parasites and microorganisms inside poultry houses, and in bird and worker welfare (Lima, 2005).

\section{PRODUCTION AND MANAGEMENT}

Today, the market imposes several restrictions on poultry meat imports. The European Union, for instance, demands that birds need to be adequately reared, and submitted to minimal welfare standards (Blokhuis, 2004).

The following five areas are crucial to success: chick quality, disease control, flock management, facilities, and feed quality. Integrations face the challenge of translating advances in genetics, nutrition, immunization, chemotherapy, health surveillance, and similar technologies into improved efficiency in growth rate, feed efficiency, and livability. This fiercely competitive business requires superior management skills to balance decisions, such as higher flock size and chick density, with improved housing, rapid growth rate, shorter rearing periods, and health programs.

\section{Rearing conditions}

Poultry meat quality is potentially affected by management techniques, weather and rearing conditions, genetics, transportation, and the ability of the birds to respond to the environment, and all the variables that may interact, affecting in the production cycle (Bertol, 2004). M ost of factors influencing poultry meat quality can be controlled during the different production stages, slaughter, and meat processing. These factors include age, gender, nutrition, management, bird density, harvesting method, environmental conditions, handling, etc. (Mendes et al., 2003)

Taking into consideration the theory of M clnerney (2004), the investment related to welfare needs to be considered as an added value by the producers, and, as pointed by Kerstin et al. (2000) and Lima (2005), the adoption of welfare standards may influence the reduction of locomotory problems in broilers. This is consistent with the study of Bolis (2001), who verified a decline in broiler productivity when birds were exposed to unfavorable rearing conditions. M addocks et al. (2001), for instance, asserted that complete confinement, resulting in the absence of access to ultra violet radiation, may cause stress in birds due to an increase in corticosterol levels.

Although the purpose of litter is to promote bird comfort, and to improve carcass quality by decreasing breast, hock, and feet lesions, there is lack of literature information on the best material, or yet, which litter material needs to be used in order to reduce its possible impact on carcass quality (Oliveira $\&$ Carvalho, 2002). Moreover, high litter moisture causes feet lesions (Julian, 2004), and increase ammonia levels inside poultry houses (M iragliotta, 2001).

Most Brazilian producers already use cooling equipment; however, many still do not know how to control wind speed and direction correctly. Several authors (Ernst, 1995; Bottcher \& Czarick, 1997; A radas et al., 2005) state that airflow over the birds can help to cool them in warm weather by decreasing effective temperature, and increasing their resistance to thermal stress. These studies demonstrated positive effect of high wind flow over the birds on physiological parameters, such as respiratory rate and deep body temperature, particularly when environmental temperatures are above the thermoneutral zone $\left(30^{\circ} \mathrm{C}\right)$. Sensitive and latent heat losses linearly increase when broilers are exposed to constant increases in wind flow. Another interesting finding was heat loss increases with wind velocity. It is possible to conclude 
Baracho MS, Camargo GA, Lima AMC, Mentem JF, Moura DJ, Moreira J, Nääs IA
Variables Impacting Poultry Meat Quality from Production to Pre-Slaughter: A Review that the use of forced ventilation leads to a more efficient removal of latent and sensible heat generated inside the broiler house.

Bressan \& Beraquet (2002), studying broiler breast meat quality, found that birds kept under heat stress (environmental temperature around $30^{\circ} \mathrm{C}$ ) presented higher cooking loss (28.7\% in average) as compared to broilers reared submitted to comfort temperature $\left(17^{\circ} \mathrm{C}\right)$, which average cooking loss was $27.2 \%$.

According to Soerensen et al. (2000), high bird density may induce to competition for space, lower feed intake, and possible feet and back lesions due to crowding around the feeders. Kerstin et al. (1999) found high statistical correlation between locomotion ability and weight gain, indicating that there is an optimum density in which these problems do not occur. Garcia et al. (2001) observed that increase in bird density leads to worse feathering and consequent improvement in heat exchange efficiency; there was also an increase in cooking loss related to high bird density. The authors also found that age influenced meat quality: from 35 to 49 days of age, cooking loss was reduced by $32.95 \%$.

Delazari (2001), when discussing welfare and productivity, asserts that stressed broilers are more susceptible to pathogen dissemination, compromising their health status.

In order to avoid dissemination of diseases, dead birds need to be removed from the poultry house as soon as possible, and appropriately disposed.

\section{Genetics}

Breeding strategies have recently taken into account meat quality in order to meet consumers needs (Gaya, 2006). Different genetic attributes, such as meat quality and carcass yield, were studied by Moreira \& Garcia (2003), who concluded that some commercial strains had better performance than others, when bird gender is considered.

According to Julian (2004), young broilers are very susceptible to variations in environmental temperature, which may lead to critical changes in metabolism due to unbalanced heat exchange. The author also points that some chemical drugs such as nicarbazin, and also chlorine and nitrophenols may make the problem yet more harmful by increasing body heat production.

Resistance to heat stress has become an important issue in the last years. Silva et al. (2001a) compared two broiler genetic strains: one with the gene $(\mathrm{Na})$, which expresses low neck feathering, and one with normal neck feathering (nana), and observed that, when exposed to heat stress (38-42 ${ }^{\circ} \mathrm{C}$ ) in an environmentally-controlled chamber, the birds with the $\mathrm{Na}$ gene presented better heat stress resistance as compared to the others. Studies report that reduced feathering volume may aid birds to optimize heat exchange in tropical conditions, becoming more tolerant to high temperature exposure ( $\mathrm{M}$ arder $\&$ Arad, 1989; Macari \& Gonzales, 1990; Singh et al., 2001; Moreira et al., 2006). In addition, non-nutritional factors, such as genetic inheritance and environment, play a vital role in the feathering rate, and may also contribute to poor feathering (M oreira et al., 2006).

\section{Nutrition}

Garcia et al. (2005) studied the inclusion of sorghum replacing corn in broiler feeds, and found a significant negative correlation between meat $\mathrm{pH}$ decrease and corn replacement. Sorghum inclusion also affected in meat color, promoting paler meat.

The influence of vitamin $E$ (as all-rac- $\alpha$-tocopheryl acetate) supplementation on the sensorial quality of frozen chicken meat was studied. Two dietary treatments were compared as follows: (1) the control group received a diet containing respectively 30, 20, and $15 \mathrm{mg}$ of $\alpha$-tocopheryl acetate $/ \mathrm{kg}$ of feed from $0-20,21-38$, and 38-45 days of age; (2) the supplemented group received a starter diet containing $30 \mathrm{mg}$ of á-tocopheryl acetate/ $\mathrm{kg}$ of feed from 0 to 20 days of age, and a finisher diet containing $200 \mathrm{mg} /$ $\mathrm{kg}$ of feed from 21 to 45 days of age. HPLC analyses showed that muscle á-tocopherol levels of the chickens fed the supplemented diet were 6-7-fold higher than those of the chickens fed the control diet. M eat quality was evaluated by sensorial as well as by instrumental techniques, such as (G-MS) thiobarbituric acid values (TBA) and gas chromatography-mass spectrometry. It was show $n$ that vitamin $E$ supplementation had a beneficial effect on sensorial data, and on oxidative stability of the meat, as measured by TBA. GC-MS analyses also showed that the concentration of aldehydes, which are considered responsible for rancid off-flavors, was much more important in the control samples as compared to the supplemented samples.

The effects of dietary a-lipoic acid (a-LA) on the $\mathrm{pH}$ value, AMP-activated protein kinase (AMPK) activation, and the activities of glycogen phosphorylase and pyruvate kinase in postmortem muscle were studied by Shen \& Du (2005). According to the authors, dietary a-LA supplementation can suppress the activation of AMPK in postmortem muscle, downregulate the activity of glycogen phosphorylase, and 
Baracho MS, Camargo GA, Lima AMC, Mentem JF, Moura DJ, Moreira J, Nääs IA
Variables Impacting Poultry Meat Quality from Production to Pre-Slaughter: A Review result in higher ultimate $\mathrm{pH}$ values in postmortem muscle. Therefore, dietary a-LA supplementation may be potentially reduce the incidence of pale, soft, and exudative (PSE) meat.

\section{Health}

In this text, the absence of health refer to biological abnormalities, which results in impaired fertility, hatchability, livability, productivity, or product quality. $M$ any diseases cause mortality or drastic postmortem tissue alterations. The susceptibility or resistance of chickens and turkeys is partially determined by genetics. Few infectious agents are potent or virulent enough to overcome natural resistance in most birds. On the other hand, most infectious agents are possibly opportunistic. They have very little obvious effect on normal, healthy, w ell-cared-for birds, but may produce severe disease and drastic losses in birds stressed by rough handling, chilling during the first weeks, poor ventilation, etc.

Some of the most common origins of diseases in broiler flocks are described below as: 1. Geneticdetermined defects; 2. Management related; 3. Feed and water related; and, 4. Infectious diseases.

1. Genetically determined defects: Some diseases have an evident genetic origin, and many others are suspected to have a genetic component. Anatomic deformities (for example, kinky back in broilers, wry neck, cystic or malformed kidneys, cystic right oviduct) are included in this category, as well as some behavioral (hysteria) and growth (poor feathering and tibial dyschondroplasia) problems. In general, major Brazilian breeding companies have done a good job in excluding these problems, and they seldom cause major constraints on productivity.

2. Management-related disease: Unfortunately, starvation, dehydration, cannibalism, ammonia blindness, and a variety of other similar diseases are uncommon. These problems can be directly related to careless or inattentive management.

3. Feed- and water-related diseases: Diseases in this category include nutritional deficiencies, intoxications, and problems associated with chemical residues. The best approach for their prevention is monitoring feed and water in order to ensure the desired quality and to decrease the risk of hazardous contaminants.

4. Infectious diseases: These diseases have so many possible origins that it is difficult to specifically pinpoint them. The most common diseases are derived from the breeder flock. Any infectious agent that is transmitted from the breeder hen through the egg to the hatched chick or poult has its ultimate origin in the breeder flock. Mycoplasmosis, salmonellosis, and avian encephalomyelitis are among the diseases that can be transmitted from breeder flocks. At the hatchery, faulty sanitation can result in several diseases, such as omphalitis, salmonellosis, and aspergillosis.

Infectious agents, which are difficult to kill by routine cleaning and disinfection, are likely to be carried over from one flock to the next simply by survival in the contaminated premises. In this category, diseases caused by clostridial spores, the erysipela bacterium, staphylococci, infectious bursal agent, adenoviruses, Marek's disease, herpes-virus, etc are included.

Biological and mechanical carriers are particularly common sources of infectious diseases. Blood-sucking arthropods (mosquitoes, blackflies, mites, ticks, etc.) are known to be involved in the transmission of diseases, such as fowl pox and spirochetosis. Rodents and free-flying birds are dangerous sources of the causative agents of cholera and salmonellosis. Flies and beetles can be carriers of a number of infectious agents, and are known to be intermediate hosts of several internal parasites.

Tibial dyschondroplasia (TD) is a common leg abnormality that occurs in rapidly growing broilers, and it is well-established that growth rate reduction caused by the use of feed restriction decreases the incidence of leg abnormalities. However, feed restriction also results in lower body weights, and therefore it is not an interesting solution to leg problems for the commercial broiler producer. Several intermittent lighting regimes, as compared to continuous lighting, are effective in reducing leg abnormalities. In addition, intermittent light reduces mortality, while promoting similar or slightly better performance than continuous light. An experiment was conducted to determine if intermittent light could result in TD decreased without reducing body weight. Two lighting programs were tested in a total of 1,010 male and female broiler chicks from three genetic lines. The presence or absence of TD, and body weights were determined at four and seven weeks of age. Low intensity x-ray imaging was used for TD diagnosis (Lixiscope). Tibial dyschondroplasia was recorded as 0 for normal broilers or 1 for broilers with an abnormal mass of cartilage accumulation in the proximal tibiotarsus. Body weight gain and feed efficiency were calculated from 0 to 4 and from 4 to 7 weeks of age. The incidence of TD at four weeks of age was 15,30 , and $5 \%$ for the $C, H$, 
Baracho MS, Camargo GA, Lima AMC, Mentem JF, Moura DJ, Moreira J, Nääs IA

Variables Impacting Poultry Meat Quality from Production to Pre-Slaughter: A Review and $\mathrm{L}$, lines, respectively. At seven weeks, incidence of TD varied from 47 to $11 \%$, and was line-dependent. At four weeks, incidence varied from 21.4 to $12.0 \%$, and at seven weeks, from 36.6 to $25.0 \%$ for males and females, respectively. Incidence of TD was reduced by intermittent light only in birds from a specific line. Tibial dyschondroplasia influenced body weights at four and seven weeks of age, independent from lighting program and sex. At four w eeks of age, broilers with TD were $32 \mathrm{~g}$ heavier than broilers with no TD. At seven weeks of age, broilers with TD were $47 \mathrm{~g}$ lighter than those with no TD. It is possible that the effect of TD on body weights depends on broiler age, and on the severity of TD lesions. There were no differences in body weight or weight gain at four or seven weeks between the lighting programs. Body weights of seven-week-old birds submitted to constant or intermittent light were 2.31 and $2.32 \mathrm{~g}$, respectively. Broilers under intermittent light had a better feed efficiency between zero and four weeks as compared to broilers exposed to constant light (1.67 and 1.71, respectively). Feed efficiency was similar from four to seven weeks in the two lighting programs (Maddocks, 2001).

Focal ulcerative dermatitis (FUD) is an ulcerative skin lesion over the breast area, usually on the unfeathered skin over the keel bone. Many factors, such as type of litter, ammonia concentration, feather loss, trauma, body weight, breast conformation, ammonia burns, and bacteria, were suggested as predisposing factors for both cellulitis and FUD, but the cause of breast lesions remains unknown (Vaillancourt \& Barnes, 2003).

Cellulitis or infectious process has emerged as an economically significant disease syndrome of broiler chickens, resulting in increased condemnations and downgrading at processing, and costs associated with trimming and reprocessing affected carcasses. Cellulitis is characterized by a diffuse inflammatory reaction in the subcutaneous tissue. Escherichia coli (E. coli) is the predominant organism isolated from cellulitis lesions in a number of studies, being considered the causing agent of cellulitis. It was shown that skin trauma or damage by scratching increase cellulitis lesion formation by E.coli. It is believed that most cellulitis lesions observed at processing started during growout (Schrader et al., 2004)

The impact of environmental risk factors on the incidence of cellulitis has not been evaluated in the United States yet. The causing agent, E. coli, is introduced through skin scratches during growout. Previous work suggested that the litter was an important reservoir for cellulitis-associated $E$. coli. Julian (2006) hypothesized that factors contributing to a positive environment for $E$. coli grow th would increase the opportunity for the exposure of broilers to an $E$. coli infectious dose capable of initiating a cellulitis lesion. A prospective study of 304 flocks in five farms from two integrated broiler companies was conducted to determine the effect of environmental factors on the prevalence of cellulitis in California broiler flocks (Schrader et al., 2004). Measured litter variables included $E$. coli and total gram-negative bacteria load (colony forming units/g dry matter), water activity, and $\mathrm{pH}$. Cellulitis ranged from $0.2 \%$ to $6.0 \%$. Significant associations were identified using linear regression among farm, litter moisture, days between flocks, and environmental temperature during the brooding period, gram-negative bacteria load in the litter during the brooding period, $\mathrm{RH}$, grow-out, and $E$. coli load late in the grow out period. The significant variation in cellulitis rate among farms, combined with a high association of litter moisture and days between flocks with cellulites, demonstrated that management decisions strongly influenced this disease syndrome. Based on these data and in previous findings, the authores advised managers to increase the number of days between flocks, and to perform a total clean out of the house if the previous flock had a high incidence of cellulitis at processing.

\section{Harvesting and transportation}

There is evidence in the literature that catching often results in injury, especially when a large number of birds are caught with maximum haste by the catching team. Leandro et al. (2001) identified and quantified losses when comparing both manual and mechanized catching (16.5 to $7 \%$, respectively). The authors found bruising in thighs, legs, and breasts of up to $25 \%$ of the harvested birds due to handling, catching, transportation, and unloading at the processing plant. However, most damage in the carcass was found during catching in the breast $(11 \%)$, thighs $(33 \%)$, and wings (38\%).

Hip dislocation occurs when birds are caught in the broiler sheds and loaded into the transportation crates. Birds are usually held by one leg, and several birds are held in each worker hand. If one or more birds start flapping their wings, their hip twists, the femur detaches, and a subcutaneous hemorrhagic is produced, killing the bird. Dead birds with dislocated hip often have blood in the mouth, which was coughed up from the respiratory tract. Sometimes, this damage 
Baracho MS, Camargo GA, Lima AMC, Mentem JF, Moura DJ, Moreira J, Nääs IA

Variables Impacting Poultry Meat Quality from Production to Pre-Slaughter: A Review is caused by too much haste by the catchers (Gregory, 1998).

Debut et al. (2004) estimated the genetic variability between lines in terms of breast and thigh meat quality (pH drop, color, drip loss, and curing-cooking yield) by comparing a slow-growing French label-type line and a fast-growing standard line (SGL) of broilers exposed to different pre-slaughter stress conditions. Birds were slaughtered under optimal conditions or after exposure to $2 \mathrm{~h}$ of transport or $2 \mathrm{~h}$ of acute-heat stress $\left(35^{\circ} \mathrm{C}\right)$. Relationships between meat quality and stress sensitivity were investigated by measuring struggle during shackling and tonic immobility (TI) duration, one week before slaughter, as an indicator of the basal level of fear of the birds. Thigh meat characteristics were influenced by both pre-slaughter stresses, but no significant effects were detected on breast meat. The main effect of heat stress on thigh meat was a decrease of the ultimate $\mathrm{pH}$, leading to paler color and lower curing-cooking yield; opposite effects were obtained for transport. Breast meat was much more sensitive to physical activity of birds on the shackle line. Longer durations of wing flapping in the shackle line produced a faster initial $\mathrm{pH}$ decline. Whatever the line, no relationship between $\mathrm{Tl}$ duration and meat quality characteristics or activity was observed. It is suggested that SGL birds could be at disadvantage due to more intense struggle during shackling, and accelerated postmortem glycolysis, which is detrimental to the quality of breast meat.

In the UK, $40 \%$ of broilers that arrive dead at the slaughterhouse may have died as a result of thermal stress and suffocation (Weeks, 2001), often due to crowding during transport. UK veterinary scientists commented on the modules in which the birds are transported: because of its compound construction, a module full of drawers tends to be poorly ventilated, particularly when the vehicle stops, whether during the journey to the processing plant or on arrival, when there is usually a delay before the birds are slaughtered. The modules may be unloaded and stacked in a lairage area. The authors recorded lairage times of up to seven hours. Deliveries of birds (92\%) were held for up to four hours before they were shackled and processed (Warris et al., 1999).

\section{Pre-slaughter stress}

Several studies were carried out to correlate preslaughter stress to meat quality. Fletcher (2002) asserts that poultry meat quality is highly dependent on preslaughter management, and that losses found at processing may be a direct result of inadequate rearing conditions, as discussed in the topic above.

Based on this concern, and encouraging welfare principles, poultry export countries are discussing specific procedures in order to ensure better meat quality to the consumers. In Brazil, this subject is included in the agenda of the Ministry of Agriculture and Food Supply (MAPA), as mentioned in Brasil (2000).

Ante mortem health inspection prevents the delivery of infected birds to processing plants (Delazari, 2001). Despite having applied this inspection during the entire life of broiler flocks, some pathological changes can still be found at slaughter (Brasil, 1998).

Losses due to high temperature at lairage, and weight loss during transportation were reported by Bilgili et al. (1989) and Mendes et al. (2001). These losses may range from 0.5 to $2 \%$ during transportation, and from 0.1 to $5 \%$ at the processing plant. In order to reduce carcass contamination, the gastrointestinal tract needs to be emptied, and this requires submitting birds to fasting six to eight hours prior to slaughter. When this time is exceeded, the intestine becomes fragile, and may release the content of the gall bladder, contaminating the carcass (M endes, 2001).

According to Savenije et al. (2002), the natural time period for chicken breast muscle to halt energy consumption is $6 \mathrm{~h}$. The muscle can maintain its internal energy balance for up to $2 \mathrm{~h}$ postmortem through other means than glycolysis. Between 4 and $6 \mathrm{~h}$ postmortem, rigor mortis sets in, after which deboning can be performed with no risk of cold shrinking. Energy consumption in the muscle is not limited by the amount of available glycogen, but rather by $\mathrm{pH}$ and by availability of Adenosine Tri-Phosphate. Glycogenolysis continues after the glycolysis has stopped. It was shown that feed withdrawal and transport quickly exhausts the main energy supplies of chickens (Savenije et al., 2002). Energy exhaustion compromises the welfare of the animals, and makes them progressively less capable of coping with further stressors. Catching, crating, and transport are stressful stimuli, but it was found that energy availability is not compromised during the short periods of time. Also, neither feed deprivation nor transport under good conditions for short periods of time significantly affected meat quality.

\section{POULTRY MEAT QUALITY}

When consumers buy a poultry meat product, cook it, and serve it to their families, they expect it to look, to taste, and to feel good in their mouth. If these 
Baracho MS, Camargo GA, Lima AMC, Mentem JF, Moura DJ, Moreira J, Nääs IA

characteristics do not meet the consumer's expectations, the product is considered to be of inferior quality. Whether or not a poultry meat product meets the consumer's expectations depends upon the conditions surrounding various stages in the bird's development, from the fertilized egg through production and processing to consumption. There are several characteristics that determine the overall quality of meat (Figure 1), according to Northcutt (1997).
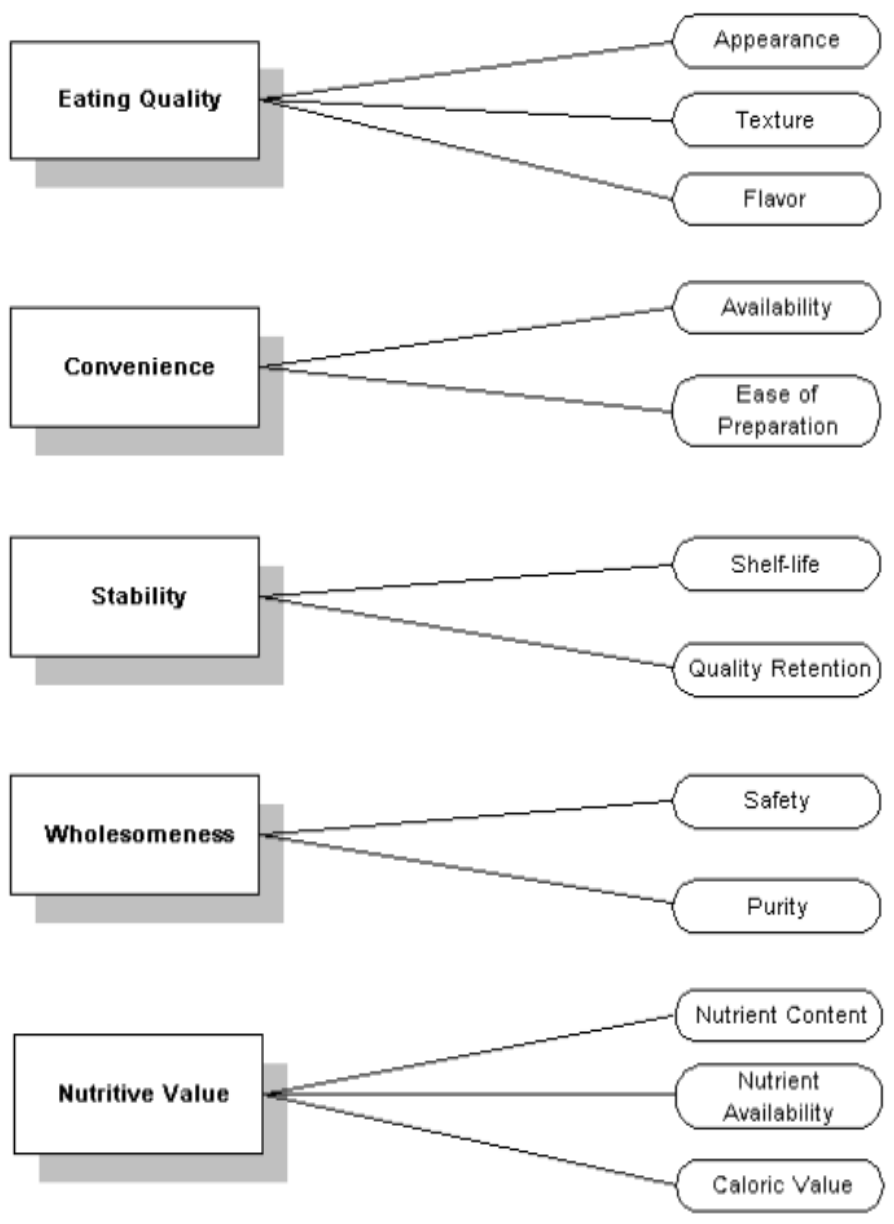

Figure 1 - Schematic view of meat attributes (Adapted from Northcutt (1997).

There are many definitions of quality. Groom (1990), taking into account the need to make products meet the demands of the market place, defines quality as:

"The composite of those characteristics that differentiate individual units of a product and which have significance in determining the degree of acceptability of that unit to the user".
The main attributes related to poultry meat that may determine its quality are color and its water holding capacity, according to Gaya (2006). The ability of preserving food in general is related to environmental air quality and temperature, as well as conditioning and packaging characteristics (Fletcher et al., 2000).

Water holding capacity (WHC) is a parameter used to describe the ability of the meat products to maintain water within its fibers (Fennema, 1990). Mendes et al. (2003) state that WHC can be measured by the difference in weight of the Pectoralis muscle before and after cooking. Castellini et al. (2002) verified that organic broiler breast and thighs presented smaller WHC values as compared to conventional broilers ( 53.2 and $57.5 \%$; and 55.3 and $60.2 \%$, respectively).

Two other important attributes, appearance and texture, of poultry meat quality are pointed out by (Fletcher, 2002). A ppearance is part of the consumer's selection of a product at the shelf, while product texture is valued by sensorial perception. The selection of carcass quality is usually based on visual criteria, and does not include all the above mentioned attributes (Mendes, 2001).

Poultry meat is a perishable product consisting of carbohydrates, protein, lipids, and water. Product conservation must meet certain standards in order to preserve its quality until consumption by the final user.

Shelf life is related to WHC and meat pH. Baruffaldi $\&$ Oliveira (1998) measured the influence of $\mathrm{pH}$ of a determined enclosed environment on the development of microorganisms. Bacteria usually grow in a $\mathrm{pH}$ range of 4.5 to 7.5 , while fungi have a wider growth range, from 2.0 to 9.0 . Fresh poultry meat has an average $\mathrm{pH}$ of 6.4 .

M uscle hemorrhages are reported as one of the major problems in poultry carcass quality (Kranen et al., 2000).

Processed broiler carcasses and raw poultry products are frequently contaminated with pathogenic microorganisms of public health significance. Muscle hemorrhages and $\mathrm{pH}$ favor the development of microorganisms.

The microbiological status of processed poultry carcasses is dependent on several key factors, namely: contamination level of live birds, number and genera of pathogenic or indicator organisms introduced during pre-harvest phases, and the extent of contamination and cross-contamination during processing (AbuRuwaida et al., 1994). Therefore, the farm of origin or conditions during live bird transportation, for instance, 
Baracho MS, Camargo GA, Lima AMC, Mentem JF, Moura DJ, Moreira J, Nääs IA
Variables Impacting Poultry Meat Quality from Production to Pre-Slaughter: A Review may be more significant in determining the levels of indicator organisms in processed carcasses than slaughter and dressing procedures (Whyte et al., 2004).

\section{Mycotoxins}

In terms of quality demanded by the international meat market, Quevedo (2005) asserts that it is important to invest in the full control of poultry production and processing in order to meet international standards and regulations. Silva (2006) describes the need of an adequate microbiological evaluation in meat production for assurance of quality, as well as consumer's safety. The amount of microorganisms that will develop during meat processing will depend on the bird's health status, and stress conditions. When a healthy bird is assessed, few microorganisms should be found, except for those on the skin surface, and in the digestive and respiratory tracts.

Mycotoxins are characterized as secondary metabolites from toxinogenic microscopic fungi, and several research studies focused on the toxins from the genus Fusarium, which is considered the largest contaminant of cereals and its by-products, particularly of corn (Flatscher \& Willinger, 1981; Leslie et al., 1990). $M$ ycotoxins may become a serious problem in Brazilian poultry production in the future due to their synergy with other infectious agents. Although 300-400 mycotoxins are already described, those causing more concern due to their incidence and toxicity are the aflatoxins, zearalenone, fumonisin, as well as the trichothecenes deoxynivalenol (DON or Vomitoxin) and toxin T-2 and T-2-like toxins (Alltech, 2000).

$M$ ycotoxins are initially found in the feedstuff, and they are disseminated throughout the poultry house after contaminated feed is distributed in the feeders. Exposure to either low or moderate levels of mycotoxins during a considerable period of time reduces productivity, leading to losses. Mycotoxin residues have been reported in poultry meat, stressing the need to control both fresh and processed food (Bezerra, 2005).

Brazilian legislation alerts to the presence only of aflatoxins in food for human consumption, establishing the limit of $30 \mu \mathrm{g} / \mathrm{kg}$ AFB1+AFG1 (ANVISA, 2001). The $M$ inistry of Agriculture and Food Supply (MAPA) limits the amount of aflatoxins in final feeds and their main feedstuffs at $20 \mu \mathrm{g} / \mathrm{kg}$ (Brasil, 1996). This limit is similar to those established in developed countries (Doll \& Peto, 1981), as well as those recommended by the World Health Organization (WHO) and the Food and
Agriculture Organization (FAO), as mentioned in FAO/ WHO (1998).

\section{Listeria}

Listeria monocytogenes has been isolated in raw poultry meat in several countries, including Brazil.

Sites and incidence of Listeria contamination in an industrial poultry processing plant were investigated by sampling carcasses at different processing stages, and by testing the hands and gloves of food handlers as well as the chilling water used in the process. In the study of Barbalho et al. (2005), 66 samples representing individual carcasses were obtained from the processing plant and analyzed for the prevalence of Listeria spp. The most frequent isolated species was $L$. innocua, which accounted for 28 out of $31(90.3 \%)$ isolates. Three $(9.7 \%)$ of the isolates were $L$. monocytogenes and two $(6.5 \%)$ were L. grayi. Listeria innocua was isolated from carcass samples at all steps of the processing line, including bleeding, scalding, defeathering, beginning and end of evisceration, and packaging. L. monocytogenes were isolated only from carcasses packaging ready to be sent to the market. No Listeria spp. was isolated from prechilling and chilling water samples. Contamination sites were detected by sampling of carcasses and workers' hands and gloves at different production stages for Listeria species by serotyping the isolates. Due to the fact that raw and processed poultry meat and workers' hands and gloves harbor Listeria, the poultry industry needs to control L. monocytogenes contamination during processing, and eventually to eliminate it from carcasses before they are sent to the market.

\section{Salmonella}

Salmonella spp., Salmonella Enteritidis, and Salmonella Typhimurium are present in chicken processing plants, as evidenced in samples of feces, feathers, scalding water, taken during evisceration, chiller water, as well as samples of rinsing water of non-eviscerated, eviscerated, and chilled carcasses. Salmonella isolates were identified by multiplex-PCR assay using three sets of primers targeting the invA, pefA, and sefA gene sequences from Salmonella spp., S. Typhimurium and S. Enteritidis, respectively. Salmonella spp. was detected in $10 \%(29 / 288)$ of the samples, whereas serovars Enteritidis and Typhimurium were identified in $62 \%(7 / 288)$ of the samples. The results suggest the need to improve hygiene and sanitary standards in poultry slaughter lines, in addition 
Baracho MS, Camargo GA, Lima AMC, Mentem JF, Moura DJ, Moreira J, Nääs IA

Variables Impacting Poultry Meat Quality from Production to Pre-Slaughter: A Review to train food handlers, and to provide information to the consumers (Savell et al., 2005; Cortez et al., 2006).

Biochemical processes and structural changes that occur in muscle during the first $24 \mathrm{~h}$ postmortem play an important role in the ultimate quality and palatability of meat, and are influenced by the chilling processes to which carcasses are submitted after slaughter. Spray chilling, a system whereby chilled water is applied to carcasses during the early part of postmortem cooling, is used to control carcass shrinkage, and to improve chilling rates during evaporative cooling. Delayed chilling can be used to reduce or to prevent the negative effects of cold shrinkage; however, production constraints in high-volume facilities and food safety concerns make this method less useful in commercial settings. Electrical stimulation and alternative carcass suspension programs offer processors the opportunity to prevent most of all effects of cold shrinkage when traditional chilling systems are used.

\section{FINAL REMARKS}

The development of new and efficient processing systems, the adoption of advanced technologies, and the introduction of novel products that meet the market chain requirements and end-consumer needs have significantly contributed to increase global poultry meat consumption (Roenigk, 1998). Poultry production and processing technologies have become readily accessible, and are implemented on a worldwide basis, thereby allowing continuous expansion and competitiveness in this meat sector (Aho, 2001).

Processing and marketing of poultry ranges from live bird markets or very primitive on-site slaughter and sale, to highly sophisticated, fully automated and International Standards Organization (ISO) certified facilities and ready-to-eat convenience products in many parts of the world. Ironically, these extremes in processing and marketing methods are sometimes observed within the same country. The lack of inadequate refrigeration is probably the single largest obstacle to the marketing of many perishable foods, including poultry meat. In many developing countries, even minute improvements in cold storage capabilities have significantly increased trade, storage, distribution, and consumption of poultry products, whether domestic or imported (Babji, 2001). In addition, the adoption of modern freezing, packaging, and transportation technologies have provided large poultry companies the flexibility to export their high quality, mostly value-added premium cuts, to all corners of the world, especially at times of domestic surpluses and low market demands (Bilgili, 2006).

Consumers worldwide demand a protein supply that is safe, wholesome, nutritious, abundant, and affordable. However, food safety standards are currently not uniform, or equally enforced, around the world. Differences, for example, in hygiene or inspection regulations often lead to trade disputes and stagnation among the countries. Several international bodies, such as the Codex Alimentarius Commission of World Health Organization (WHO), the Food and Agricultural Organization (FAO), the International Commission on Microbiological Specifications for Foods (ICMSF), and the World Trade Organization (WTO) Agreements on Sanitary and Phytosanitary Measures (SPS) and Technical Barriers to Trade (TBT) develop and provide guidelines for the equivalency in international standards to protect the health of consumers and to ensure fair practices in food trade (Bilgili, 1999).

Welfare and good production practices on the farm, during transportation, and in the processing plant should be observed at all times, and be incorporated as part of an effective poultry production system. Adequate welfare procedures and proper hygiene must minimize dyschondroplasias, cellulitis, dermatitis, and exposure of carcasses to fecal material and potential pathogens, reducing the opportunities of cross-contamination.

As the world moves towards a global market economy, poultry production will continue to increase in countries with important natural resources and that are economically competitive and politically open to business investments (Aho, 2001). M any countries or regions, on the other hand, will continue to struggle to compete in this market, either because of limited infrastructure (raw materials, land, utilities, labor, transportation) or political constraints (environmental and welfare concerns, tax structure, trade policies).

In 2003 and 2004, outbreaks of high pathogenic avian influenza in Asia led to the disruption of production and exports from key poultry producing nations. In Japan, the world's second largest poultry meat importing nation, poultry meat consumption significantly declined after these events. However, in the second half of 2004, a period in which US beef was excluded from Japan as a result of the discovery of BSE, limited supplies and subsequently higher beef prices resulted in a recovery in Japanese poultry meat consumption (Bailey, 2005). 
Before poultry meat quality is addressed, it must be clearly defined how the term quality is related to poultry meat. This is a difficult task, because quality is "in the eye of the beholder". For example, someone trying to sell a product may consider quality in terms of how well the product is sold and how many people is willing to pay for it. However, this definition is incomplete, as it does not take into account product characteristics. As people only buy what they like, the consumer's perception of quality is the ultimate definition of quality, which needs to be met by poultry meat producing countries.

\section{REFERENCES}

Abu-Ruwaida AS, Sawaya WN, Dashti BH, Murad M, Al-Othman HA. Microbiological quality of broilers during processing in a modern commercial slaughterhouse in Kuwait. Journal of Food Protection 1994; 57:887-892.

Agência Nacional de Vigilância Sanitária .Legislação. [Accessed dec. 08, 2006]. Available from: URL:http://w w w.anvisa.gov.br

Aho P. The new poultry elite. WATT Poultry USA, may, 20-24.

Almeida Filho N, Rouquayrol MZ. Desenhos de pesquisa em epidemiologia: epidemiologia e saúde. 5. ed. Rio de Janeiro: MEDSI; 1999.

Almeida IAZC. Salmonella: sorotipos identificados na região de São José do Rio Preto/SP, no período de 1990-1999. Revista do Instituto Adolfo Lutz 2000; 59(1/2):33-37.

AL-TECH, Comércio e Importação Ltda. Compreendendo e lidando com os efeitos das micotoxinas em rações e forragens para animais domésticos. [Acesso dez. 8,. 2006]. Disponível em: URL: http:// www.altech.com.br/i01.htm.

A radas ME, NääsI, Salgado IA. Comparing the thermal environment in broiler houses using two bird densities under tropical conditions. Agricultural Engineering International 2005; 8:1-9.

Babji AS. Asian poultry processing adjusts to domestic market demands. World Poultry 2001; 17:22-24.

Baley D. Beef and veal, pigs and poultry: meat outlook to 200910. Australian Commodities 2005; 12(1):65.

Barbalho TCF, Almeida PF, Almeida RCC, Hofer E. Prevalence of Listeria spp. at a poultry processing plant in Brazil and a phage test for rapid confirmation of suspect colonies. Food Control 2005; 16:211-216.

Baruffaldi R, Oliveira M N. Fatores que condicionam a estabilidade de alimentos. In: Fundamentos de tecnologia de alimentos. São Paulo: Atheneu; 1998. p.13-25.

Bertol TM . Estresse pré-abate: conseqüências para a sobrevivência e a qualidade da carne em suínos. [Accessed out. 15, 2006].
Available from: URL: http://w ww.cnpsa.embrapa.br/?/artigos/2004/ artigo-2004-n004.html.

Bezerra V S. [Accessed dec. 08, 2006]. Available from: URL: http:// w w w .embrapa.br/noticias/artigos/folder.2005-0202.1550581232/artigo.2005-06-14.3711997257/.

Bilgili SF, Egbert WR, Hoffman DL. Research note: effect of postmortem ageing temperature on sarcomere lengh and tenderness of broiler Pectoralis major. Poultry Science 1989; 68(11):1588-1591.

Bilgili SF. Assuring the safety of poultry products in a global market: The US perspective. In: Proceedings of the XIV European Symposium on the Quality of Poultry Meat; 1999; Bologna, Italy. p.513-519.

Bilgili SF. Poultry Products and Processing. In: The International Market Place. Auburn: Department of Poultry Science Auburn University; 2006. p.8.

Blokhuis HJ. Recent developments in european and international welfare regulations. World's Poultry Science Journal 2004; 60(4):469-477.

Bolis DA. Biosseguridade na criação alternativa de frangos. In: Conferência Apinco de Ciência e Tecnologia Avícola; 2001; Campinas, São Paulo. Brasil. p.223-234.

Brasil. Ministério da Agricultura, Pecuária e do Abastecimento. Regulamento técnico da Inspeção tecnológica e higiênico-sanitária de carne de aves: Portaria DAS, n‥ 210, de 10 de novembro de 1998, republicada em 05.03.99. [Accessed dec. 12, 2004]. Available from: URL: http://www.agricultura.gov.br/sda/dipoa/ republport210.html.

Brasil. Ministério da Agricultura, Pecuária e do Abastecimento. Regulamento técnico de métodos de insensibilização para o abate humanitário de animais de açougue: instrução normativa n.3, de 17 de janeiro de 2000. Brasília: [s.n]; 2000.

Brasil. Portaria MAARA No.183 de 21 de março de 1996. Diário Oficial da União, Brasília (DF); 25 de março de 1996; Seção I. p. 4929.

Bressan MC, Beraquet NJ. Efeito de fatores pré-abate sobre a qualidade da carne de peito de frango. Ciência Agrotécnica 2002; 26(5):1049-1059.

Castellini C, Mugnai C, Dal Bosco A. Effect of conventional versus organic method of production on the broiler carcass and meat quality. Meat Science 2002; 60:219-225.

Delazari I. Abate e processamento de carne de aves para garantia de qualidade. In: Conferência Apinco de Ciência e Tecnologia Avícola; 2001; Campinas, São Paulo. Brasil. p.191-203.

Delazari I. Programas de segurança de alimentos na indústria da carne. Avew orld 2004; 1:44-49.

Doll R, Peto R. The causes of cancer: quantitative estimates of avoidable risks of cancer in the United States today. Journal of National Cancer Institute 1981; 66:1191-308. 
Baracho MS, Camargo GA, Lima AMC, Mentem JF, Moura DJ, Moreira J, Nääs IA

Variables Impacting Poultry Meat Quality from Production to Pre-Slaughter: A Review

Escudero-Gilete ML, González-M iret ML, Moreno Temprano $\mathrm{R}$ Heredia FJ. A pplication of a multivariate concentric method system for the location of Listeria monocytogenes in a poultry slaughterhouse. Food Control 2007; 18(1):69-75.

FAO/WHO. Expert Committee on Food Aditives [JECFA]. Safety evaluation of certain food additives and contaminants - Aflatoxins. Geneva: World Health Organization; 1998.

Fennema OR. Comparative water holding properties of various muscle food. Journal of Muscle Foods 1990; 1:363-381.

Flatscher J, Willinger $\mathrm{H}$. Bakterien-und pilzkeimzahlen in futtermitteln. wiener tierärztliche monatsschrift. In: Findlay, WPK. Fungi: folklore, fiction \& fact. Surrey: Kingprint 1982; 68:282284.

Fletcher DL. Poultry meat quality. World's Poultry Science Journal 2002; 58(2):131-145.

Fletcher DL, Qiao M, Smith DP. The relationship of raw broiler breast meat color and $\mathrm{pH}$ to cooked meat color and $\mathrm{pH}$. Poultry Science 2000; 79 (5):784-788.

Garcia RG, M endes AA, Costa C, Paz ICLA, Takahashi SE, Pelícia KP, Komiyama CM, Quinteiro RR. Desempenho e qualidade da carne de frangos de corte alimentados com diferentes níveis de sorgo em substituição ao milho. Arquivo Brasileiro de Medicina Veterinária e Zootecnia 2005; 57(5):634-643.

Garcia RG, Mendes AA, Garcia EA, Nääs IA, Moreira J, Almeida ICL, Takita TS. Effect of stocking density and sex on feathering, body injury and breast meat quality of broiler chikens. Brazilian Journal of Poultry Science 2001; 1(4):1-9.

Gasparetto KM PO. Sorotipos de Salmonella isolados de carcaças de frango e avaliação da susceptibilidade a antimicrobianos. Revista Ciência Farmacêutica 2001; 2(2):85-199.

Gast RK. Salmonella infections. In: Saif YM editor. Diseases of poultry. $11^{\text {th }}$ ed. Ames: lowa State Press; 2003. p. 567-583.

Gaya LG, Ferraz JBS. Aspectos genético-quantitativos da qualidade da carne em frangos. Ciência Rural 2006; 36(1):349-356.

Groom GM. Factors affecting poultry meat quality. In: Options méditerranéennes Cambrigde (UK): Agricultural Development and Advisory Service (ADAS), Fisheries and Food, Cambridge (UK); 1990. (Série A-L'aviculture en M éditerranée).

Heier BT, Hogasen HR, Jarp J. Factors associated with mortality in Norwegian broiler flocks. Preventive Veterinary Medicine 2002; 53(1-2):147-158.

Julian RJ. Production and growth related disorders and other metabolic diseases of poultry: a review. The Veterinary Journal (in press). [Accessed dec. 10, 2006]. Available from: URL: http:// www.sciencedirect.com.

Kranen RW. Haemorrhages in muscles of broiler chickens. World's Poultry Science Journal 2000; 56(2):93-126.
Leandro NSM. Efeito do tipo de captura dos frangos de corte sobre a qualidade de carcaça. Ciência Animal Brasileira 2001; juldez: 97-100.

Leslie JF, Pearson CHAS, Nelson PE, Toussoun TA. Fusarium spp. from corn, sorghum and Soybean Fields in the Central and Eastern United States. Phytopathology 1987; 80:334-350.

Lima AM C. Avaliação de dois sistemas de produção de frango de corte: uma visão multidisciplinar [tese]. Campinas (SP): Universidade Estadual de Campinas; 2005.

Maciorowski KG. Incidence, sources, and control of food-borne Salmonella spp. In poultry feeds. World's Poultry Science Journal 2004; 60(4):446-457.

Maddocks SA. Behavioural and physiological effects of absence of ultraviolet wavelengths for domestic chicks. Animal Behaviour 2001; 62:1013-1019.

Matheus DP, Rudge AC, Gomes SM M. Ocorrência de Salmonella spp em carne de frango comercializada no município de Bauru (SP), Brasil. Revista do Instituto Adolfo Lutz 2003; 62(2):111-115.

M clnerney J. Animal welfare, economics and policy: report on a study undertaken for the farm \& animal health economics. Londres: Division of DEFRA; 2004.

Mendes AA. Rendimento e qualidade da carcaça de frangos de corte. In: Conferência Apinco de Ciência e Tecnologia Avícolas; 2001; Campinas, São Paulo. Brasil. p.79-99.

M iragliotta MY. Avaliação de dois sistemas de ventilação de densidade e sua influência sobre níveis de amônia em sistema de produção de frangos de corte [dissertação]. Campinas (SP): Universidade Estadual de Campinas; 2001.

Moreira J, Garcia RG. Qualidade da carne de peito de frango de corte. Revista Nacional da Carne jul/2003; 317:14-19.

Moreira J, Mendes AA, Garcia RG, Garcia EA, Roça RO, Nääs IA Dalanezi JA, Pelícia K. Evaluation of strain, dietary energy level and stocking density on broiler feathering. Revista Brasileira de Ciência Avícola 2006; 8(1):15-22.

Moss MO. Fungal Biotechnology Roundup. Mycologist 1990; 21:55-58.

Northcutt JK. Factors affecting poultry meat quality. Bulletin 1157 1997. [Accessed nov. 18, 2006]. Available from: URL:http// pubs.caes.uga.edu.

Oliveira CM, Carvalho DI. Rendimento e lesões em carcaças de frangos de corte criados em diferentes camas e densidades populacionais. Ciência Agrotécnica 2002; 26(5):1076-1081.

Quevedo A. Frango à brasileira. [Accessed aug. 16, 2005]. Available from: URL: http://www.aviculturaindustrial.com.br/site/ dinamica.asp? id=12036\&tipo_tabela =negocios\&categoria = mercado_interno. 
Roenigk WP. Poultry will overtake pig meat consumption. World Poultry 1998; 14(12):14-16.

Santos DMS. Salmonella em carcaças de frango congeladas. Pesquisa Veterinária Brasileira 2000; 20(1):39-42.

Savenije B, Lambooij E, Gerritzen M A, Venema K, Korf J. Effects of Feed Deprivation and Transport on Preslaughter Blood Metabolites, Early Postmortem Muscle M etabolites, and Meat Quality. Poultry Science 2002; 81:699-708.

Schrader JS, Singer RS, Atwill ER. A prospective study of management and litter variables associated with cellulitis in California broiler flocks. Avian Diseases 2004; 48:522-530.

Silva MAN, Silva IJO, Piedade SMS. Resistance to heat stress of naked neck broilers. Revista Brasileira de Ciência Avícola 2001a; 3(1):27-33.

Silva N, Junqueira VCA, Silveira NFA. Manual de métodos de análise microbiológica de alimentos. 2. ed. São Paulo: Varela; 2001b.

Soerensen P, Su G, Kestin SC. Effects of age and stocking density on leg weakness in broiler chickens. Poultry Science 2000; 79:864870.

Tinôco IFF. Avicultura Industrial: novos conceitos de materiais, concepções e técnicas construtivas disponíveis para galpões avícolas Brasileiros. Revista Brasileira de A vicultura 2001; 3 (1):0126.

UBA: União Brasileira de Avicultura. Relatório anual 2003/ 2004.[Accessed feb. 20, 2005]. Available from: URL: http:// www.uba.br/2005.

Valdes C. Brazil Emerges as M ajor Force in Global Meat Markets. Livestock, Dairy, and Poultry Outlook, Mildred Haley. LDP-M-137 - LDP-M-139, USDA, Economic Research Service, January 2006. [Accessed dec. 08, 2006]. Available from: URL: ww w.ers.usda.gov/ publications/ldp/.

Warriss PD, Knowles TG, Brown SN, Edwards JE, Ketlewell PJ, $M$ itchell M A, Baxter CA. Effects of lairage time on body temperature and glycogen reserves of broiler chickens held in transport modules. Veterinary Record 1999; 145:218-222. 